\author{
SERIES 'CELL BIOLOGY OF RESPIRATORY MUSCLES' \\ Edited by M. Decramer and M. Aubier \\ Number 2 in this Series
}

\title{
Myosin gene expression in the respiratory muscles
}

\author{
J.G. Gea
}

\begin{abstract}
Myosin gene expression in the respiratory muscles. J.G. Gea. CERS Journals Ltd 1997. ABSTRACT: Myosin is one of the basic structural components of skeletal muscles. Its interaction with actin results in muscle contraction. The myosin molecule is composed of two heavy (MyHC) and two light chains (MyLC) that, together with the adenosine triphosphatase (ATPase) activity, determine the functional characteristics of the fibre. Both MyHC and MyLC present different isoforms. The main MyHC isoforms in adult mammals are the slow MyHC (MyHC-I) and fast MyHCs (MyHC-IIa, MyHC-IIb and MyHC-IIx). Muscle fibres can express only one isoform or coexpress different forms.

The muscle phenotype is the product of genome plus environmental stimuli. The family of genes that codifies the MyHC isoforms is located in two different clusters, each isoform being encoded by a separate gene. The gene corresponding to slow MyHC is located in chromosome 14, both in humans and in mice. The other genes are positioned in chromosome 17 in humans, and in chromosome 11 in mice. The transcriptional and translational mechanisms that control the expression of MyHC isoforms are not well known, although it is believed that the main regulation is dependent on mechanical signals. These signals are probably mediated by a biochemical messenger. As a general rule, fast MyHC genes seem to be expressed "by default", whereas the slow MyHC gene would be expressed as a response to changes in load.

So far, few studies have analysed the in vivo regulation of MyHC gene expression in respiratory muscles. It has recently been reported that breathing against moderate levels of inspiratory resistance quickly induces an increase in the genetic expression of slow MyHC in the diaphragm. This suggests the possibility of eliciting a phenotypic adaptation of respiratory muscles using specific training protocols. Eur Respir J 1997; 10: 2404-2410.
\end{abstract}

Muscles are extremely plastic, and are capable of modifying their structure to the activity they develop [1-4]. At the molecular level, muscles are composed of different structural and enzymatic elements, whose genetic expression is modulated by such activity. Myosin is one of the main structural components of the skeletal muscles, which include respiratory muscles. This myofibrillar protein (fig. 1), essential for muscle contraction, is composed of two heavy (MyHC) and two light chains (MyLC). The MyHC (molecular weight $220 \mathrm{kDa}$ ) has a globular portion at one of its ends (amino-terminal part). This site is called the "head" (or $\mathrm{S}_{1}$ ) of the molecule, and is the site of interaction with actin. This is also the site of action for the actomyosin adenosine triphosphatase (ATPase). The two MyLC (molecular weights, 17-23 $\mathrm{kDa}$ ) are located very close to this portion, in the "neck" of the molecule. On the other side, there is an alphahelicoidal structure (carboxy-terminal part) called the "tail". Both MyHC and MyLC present different isoforms. The presence of one or another isoform conditions the acti-vity of the myosinic ATPase [5], and these two factors determine the maximum velocity of shortening, the predominant metabolism of the fibre and its resistance to fatigue [1, 6-10]. In this regard, those fibres containing slow MyHC isoforms present a smaller contraction velo- city but higher metabolic efficiency for maintaining similar levels of tension [11]. The relationship between the MyHC composition and fibrillar function has been evidenced, not only in skeletal limb muscles but also in the diaphragm [12]. The MyLC isoforms are involved in force transduction, and, thus, in the mechanical efficiency and economy of different kinds of contraction [13].
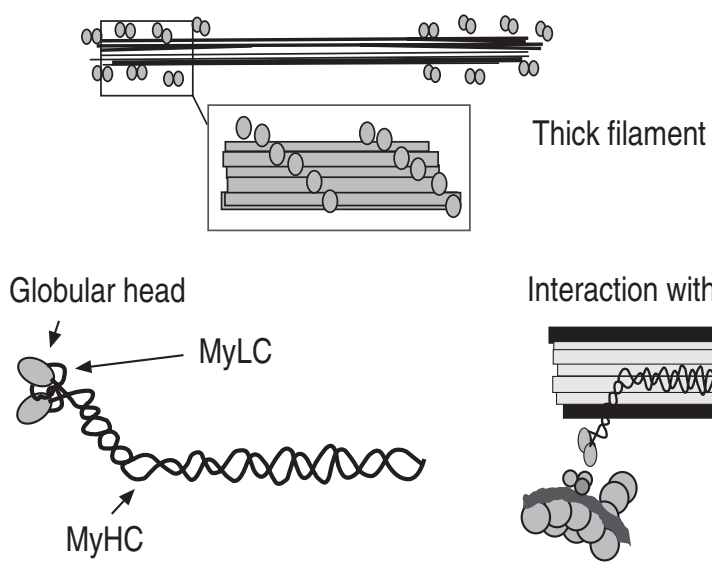

Interaction with actin

Fig. 1. - Molecular structure of myosin. MyLC: myosin light chain; MyHC: myosin heavy chain. 
In the skeletal muscles of adult mammals, four main types of MyHC have been described: one slow (slowMyHC, MyHC-I or beta-MyHC) and three fast (MyHCIIa, MyHC-IIb and MyHC-IIx) [14, 15]. In the early stages of development, foetal as well as neonatal MyHC isoforms exist. On the other hand, there are three main MyLC isoforms, MyLC1s, MyLC1f and MyLC3f. It is likely that these classifications still remain incomplete, above all regarding slow isoforms $[14,15]$. The structure of different MyHC isoforms is similar among different species, and their velocity of contraction is specific for each isoform $[1,6,7,12,16,17]$. Fibres containing MyHC-IIa have a velocity of shortening very close to those containing MyHC-IIx, and lower than those fibres containing MyHC-IIb [7, 12, 17]. The four main MyHC isoforms determine the four types of fibres (I, IIa, IIb and IIx) [18], although there are also mixed fibres, with different combinations of MyHC isoforms [18-23]. Generally, mixed fibres showed MyHC isoforms with similar functional and biochemical characteristics (i.e. MyHC-IIa and MyHC-IIx). However, it is also possible to detect fibres containing $\mathrm{MyHC}$ with very "incongruous" properties (i.e. MyHC-I in fast fibres). In human beings, fibres type I and type IIa are composed mainly of their corresponding isoforms (MyHC-I and MyHC-IIa, respectively). However, and interestingly, type IIb fibres seem to be predominantly formed by an isoform equivalent to the MyHC-IIx of rodents [18]. This is important for the respiratory muscles, since the diaphragm has a high proportion of this MyHC in many species [24]. The presence of MyHC-IIx and the presence of abundant oxidative enzymes [25], provide the respiratory muscle fibres with an important level of resistance to fatigue [26].

The expression of MyHC isoforms in the diaphragm varies from one species to another. In humans, slow and fast $\mathrm{MyHC}$ isoforms are expressed in similar amounts [27]. The same occurs in rats [28-30]. Interestingly, there is almost no MyHC-IIb in the latter animal [30]. By contrast, mongrel dogs show a higher expression of the fast MyHC isoform in this muscle [31]. The expression appears as homogeneous throughout the diaphragm, with no differences between the costal and the crural portions [31].

As mentioned above, the skeletal muscle has a great capacity for structural adaptation. The phenotypic characteristics of a muscle are determined by genes and the influences of the environment on their expression [32]. In recent years, techniques in molecular biology have made it possible to identify the genes encoding the different MyHC and MyLC isoforms [33]. These genes form three multigenic families, each one probably being derived from a common gene, called the "ancestor gene". The superfamily of genes encoding MyHCs is composed of different genes, each one appearing to encode one specific isoform. The MyHC genes are located in two clusters (fig. 2). The one for slow MyHC is located in chromosome 14, closely linked to that of cardiac alphaMyHC, both in humans and mice [34-36]. The other MyHC genes, including those encoding fast MyHC isoforms, but also foetal and perinatal MyHC, are clustered in chromosome 17 in humans, and in chromosome 11 in mice $[36,37]$. At least six genes exist in this cluster $[38,39]$, and it is believed that there is a specific

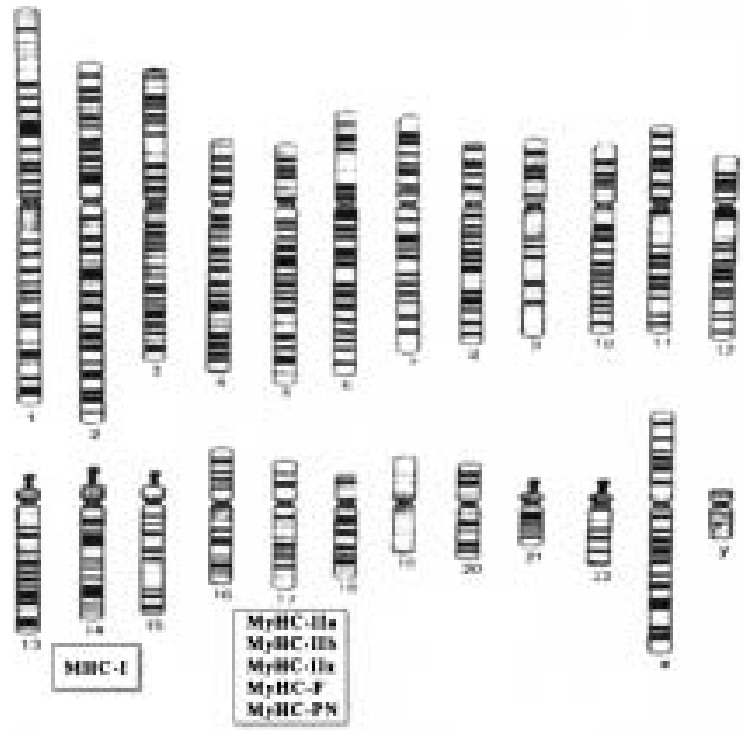

Fig. 2. - In humans, the genes for slow myosin heavy chain (MyHCI) are clustered in chromosome 14, whereas those for fast, foetal and perinatal myosin heavy chain (MyHC-IIa, b and x, -F and -PN, respectively) are located in chromosome 17.

gene for each one of the fast isoforms (MyHC-IIa, MyHC-IIb and MyHC-IIx) [33].

Genes are transcribed into messenger ribonucleic acids (mRNAs), that are specific for each isoform. Studies using in situ hybridization (ISH) have made it possible to identify these mRNAs. This has improved knowledge of the next steps necessary for the synthesis of MyHC molecules and their assembly in the thick filament of the sarcomere [40-42]. The mRNAs corresponding to MyHC have been detected predominantly in the periphery of the fibres, surrounding the nuclei [43] (fig. 3). Smaller concentrations have been observed close to the A-band of the sarcomere. This suggests both that the message and not the product (MyHC) emigrate to the incorporation site, and that the MyHC translation ends up in the interfibrillar space, in the periphery of the myofibril [44-46]. There, the new MyHC diffuses and is incorporated throughout the width and length of the A-band [46]. The studies using ISH have also confirmed the heterogeneity of many fibres, that simultaneously coexpress genes encoding different MyHC isoforms [33].

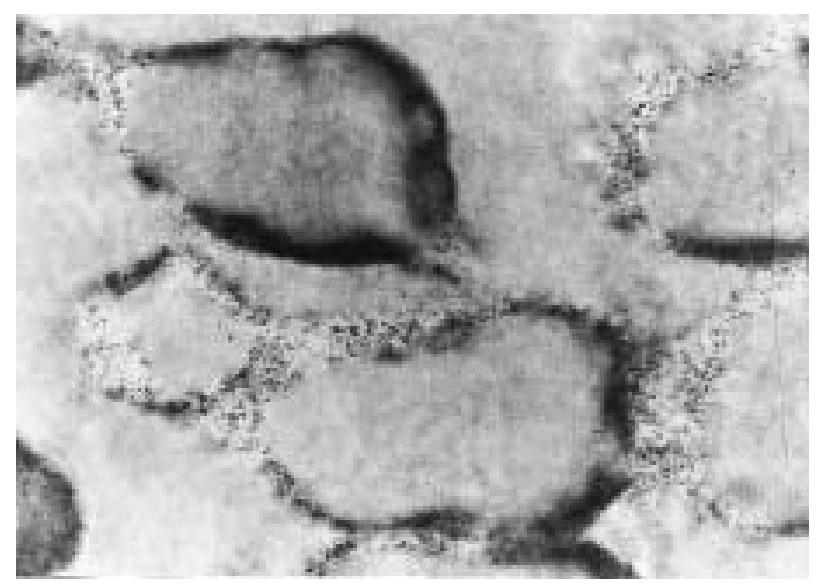

Fig. 3. - Expression of messenger ribonucleic acid (mRNA) corresponding to slow myosin heavy chain observed in a cross-sectional view of fibres from the diaphragm. 
The transcriptional and translational mechanisms that regulate the expression of the genes encoding $\mathrm{MyHC}$ isoforms are not well-known, although they are being actively investigated. It is believed that the expression is regulated fundamentally by mechanical signals, particularly by changes in the tension generated by the muscle during the effort [47]. The stretch (active tension) as well as electrical stimulation (passive tension) provoke the repression of the fast-type genes, with activation of the slow-type genes [2, 48]. This implies a progressive transformation in the type of fibres [49-52]. This transformation is not dependent on their substitution by new fibres, but on changes in the molecular expression of their MyHC isoforms [53]. As a general rule, the fast-type genes seem to be expressed "by default", whereas the slow-type genes would be expressed as a response to changes in loads [50-52]. Thus, a decrease in or lack of activity would result in a higher expression of fast $\mathrm{MyHC}$, with an increase in the size and/or proportion of type I fibres [54-58]. However, the type of activity also influences the expression [59]. For example, aerobic exercises trigger the expression of slow MyHC, whereas weight-lifting training induces a greater expression of fast MyHC [59]. Rest and weight-lifting exercises act in different ways, increasing the expression of fast MyHC. Whereas the latter provoke an increase in expression of fast $\mathrm{MyHC}$ in fast fibres that become hypertrophic, the decrease in activity results in a higher expression of fast $\mathrm{MyHC}$ in the overall population of fibres. Apparently, transitions among different types of MyHC seem to follow an order established by their functional characteristics. Thus, MyHC-I would be substituted by MyHC-IIa, which in turn would be sequentially replaced by MyHC-IIx and MyHC-IIb [60, 61]. This sequence would operate in both directions, according to the type of stimulus experienced.

As mentioned previously, mechanical signals are believed to be the main stimulus capable of inducing changes in the expression of MyHC isoforms. The effects of active tension have been studied, submitting the muscle either to an increase or decrease in loads [54, 6264]. For the former, muscle overloading [50, 64, 65] and training [59, 66-71] were used. In contrast, suspension [50, 54, 57, 65, 67, 72], immobilization [2, 72] and microgravity $[56,73]$ were employed to reduce the loads. On the other hand, passive tension has been evaluated through studies using different patterns of neural activity [1, 51, 74-77]: electrical stimulation [51, 53, 77-81]; muscle blockade [83-85]; and denervation [82]. Finally, hormonal factors, such as the effects of thyroid hormone or steroids, also influence the expression of different MyHC isoforms [66, 86-88]. The above-mentioned factors were used both separately and in a combined form to evaluate the specific weight of each one $[65,67]$

Nutrition is an additional factor that can modulate the genetic expression of MyHC. Some dietary deficiencies during development [89], and local ischaemia [90], appear to favour the expression of slow MyHC. Sex, degree of development and ageing are other factors that condition the expression of MyHC [91]. At the moment of birth, skeletal muscles show a combination of embryonic and neonatal MyHC, with small quantities of MyHCI and MyHC-IIa. The embryonic MyHC is progressively substituted by adult forms [92, 93]. Ageing involves new changes in expression. As an example, MyHC-IIb is substituted by MyHC-IIx in older rats [94].

A point of interest is the intensity of the stimulus capable of triggering changes in the genetic expression of MyHC. Although even moderate loads are capable of modifying this expression [31], the minimum threshold required to induce the transformation still remains unknown. In general, the intensity and velocity of the changes vary from one animal species to another [95]. A factor that should also be considered is the duration of the stimulus required for transformation [96]. In adult animals, changes have been observed even after extremely short periods of stimulation [48].

It is believed that changes in the tension generated by the muscle during the effort would be the initial phenomenon involved in the transformation process [47]. A fascinating question is how changes in tension result in changes in MyHC gene expression. The signal could act just mechanically or through the release of a messenger. However, recent studies suggest that the muscular activity itself is not sufficient for triggering the process [47]. Nevertheless, the link between the mechanical signal and changes in MyHC gene expression remains undiscovered. It is possible that some of the mediators that act in the early stages of development, such as myogenin and/or MyoD, could be implicated [97]. The persistent decrease in the potential of phosphorylation in the adenosine triphosphate (ATP) system has also been suggested as a potential trigger for MyHC transformation [95]. In addition, a growth factor that has recently been cloned from muscles subjected to stress can also be implicated in this genetic modulation [98]. On the other hand, membrane and sarcomere damage have been observed in muscles after moderate loading [99]. This damage coexists with changes in the genetic expression of MyHC [31], and with the presence of the above-mentioned growth factor [98]. The relationship between muscle damage and changes in MyHC expression is also unknown. The first event may be a prerequisite for gene switching or just a different part of the same remodelling process, not directly related to the latter.

The capacity of muscles to adapt to a variety of challenges has been explored mainly in the field of sports medicine, and in the treatment of cardiac diseases with myocardial substitutes $[100,101]$. There are few studies evaluating these phenomena in respiratory muscles. In general, the results are quite similar to those observed in other skeletal muscles submitted to loads [83, 101, 102]. Interestingly, general training, although prolonged, appears to result in only mild changes in the cellular and molecular characteristics of the diaphragm [103]. In addition, changes appear to affect just the costal portion of the diaphragm. In contrast, we have recently observed that specific respiratory stimuli are capable of dramatically modifying the structure of this muscle in vivo. Breathing against moderate levels of inspiratory resistance resulted in an increase in the expression of the genes encoding the slow MyHC [31]. These changes affected both the costal and crural portions of the diaphragm. The transient submission to respiratory loads probably emulated an endurance training, with similar results in $\mathrm{MyHC}$ expression [70]. The nature of these 


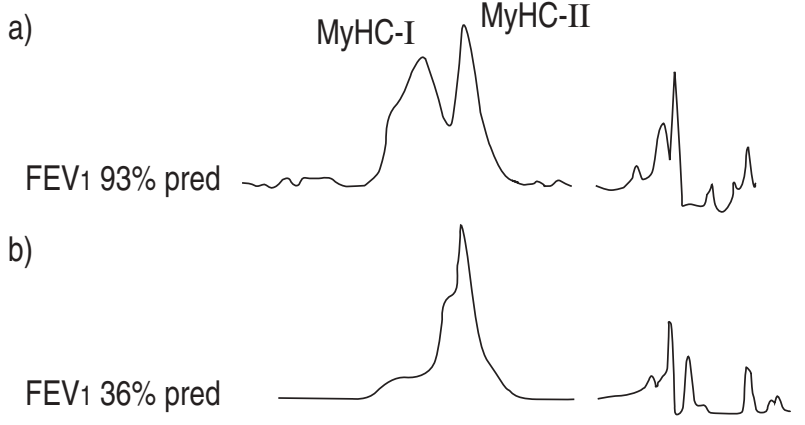

Fig. 4. - Densitometric profiles of slow (MyHC-I) and fast myosin (MyHC-II) heavy chain isoforms obtained in electrophoresis from the external intercostal muscles of subjects with: a) normal lung function; and b) severe chronic obstructive pulmonary disease (COPD). FEV1: forced expiratory volume in one second; $\%$ pred: percentage of predicted value.

changes is presumably adaptive. Thus, the phenotypic reprogramming of the muscle with a greater expression of genes encoding slow MyHC would condition multiple metabolic and mechanical advantages. The smaller energy cost necessary to maintain a similar tension $[5$, $11,104]$, would be added to a higher resistance to fatigue [70]. However, not everything is beneficial; these changes would also result in a higher curvature of the forcevelocity relationship in the muscle, with loss both of velocity and strength of contraction [7, 8, 17]. On the other hand, it has recently been observed that external intercostal muscles show an increased expression of fast MyHC in patients with chronic obstructive pulmonary disease (COPD) [105] (fig. 4). This increase, in the opposite direction to what one would expect in the diaphragm, is probably related to the type of activity that external intercostals have to develop in COPD patients. On the other hand, our group was not able to demonstrate changes in the expression of $\mathrm{MyHC}$ in the diaphragm of these patients [27]. However, this could have been due to the fact that patients with severe airways obstruction were not included.

An interesting implication of these studies is that they suggest the possibility of eliciting a phenotypic adaptation of the diaphragm in humans using training programmes. The beneficiaries of such programmes would be mainly COPD patients, but also those individuals submitted to long-term mechanical ventilation. The programmes should be designed to achieve specific objectives. Improving the strength of respiratory muscles can be useful for some functions (i.e. cough and sighs in exacerbations of chronic respiratory diseases), whereas increasing the endurance would be useful in others (i.e. exercise tolerance). Possibilities other than training could probably be contemplated in the near future, such as the use of drugs known to modify the genetic expression of structural proteins, or the use of genetic therapies to induce the synthesis of endogenous growth factors in the muscle.

Acknowledgements: The author acknowledges J. MartínCampos for his critical comments, and J.A. Salazar for his editorial assistance.

\section{References}

1. Salmons S, Sreter FA. Significance of impulse activity in the transformation of skeletal muscle type. Nature 1976; 263: 30-34.
2. Goldspink G, Scutt A, Loughna PT, Wells DJ, Jaenicke $\mathrm{T}$, Gerlach GF. Gene expression in skeletal muscle in response to stretch and force generation. Am J Physiol 1992; 262: R356-R363.

3. Pette D. The dynamic state of muscle fibers. Berlin, Walter de Gruyter \& Co., 1990.

4. Hoppeler H. Exercise-induced ultrastructural changes in skeletal muscle. Int J Sports Med 1986; 7: 76-92.

5. Bottinelli R, Canepari M, Reggiani C, Stienen GJM. Myofibrillar ATPase activity during isometric contraction and isomyosin composition of rat single skinned muscle fibres. J Physiol (Lond) 1994; 481: 663-675.

6. Watchko JF, Sieck GC. Respiratory muscle fatigue resistance relates to myosin phenotype and SDH activity during development. J Appl Physiol 1993; 75: 13411347.

7. Sweeney HL, Kushmerick MJ, Mabuchi K, Sreter FA, Gergely J. Myosin alkali light chain and heavy chain variations correlate with altered shortening velocity of isolated skeletal muscle fibers. J Biol Chem 1988; 263 : 9034-9039.

8. Reiser PJ, Moss RL, Giulian GG, Greaser ML. Shortening velocity in single fibres from adult rabbit soleus muscle is correlated with myosin heavy chain composition. J Biol Chem 1985; 260: 9077-9080.

9. Barany M. ATPase activity of myosin correlated with speed of muscle shortening. J Gen Physiol 1967; 50: 197-218.

10. Close R. The relationship between intrinsic speed of shortening and duration of the active state of muscle. $J$ Physiol (Lond) 1965; 180: 542-559.

11. Crow MT, Kushmerick MJ. Chemical energetics of slowand fast-twitch muscles of the mouse. J Gen Physiol 1982; 79: 147-166.

12. Eddinger TJ, Moss RL. Mechanical properties of skinned single fibers of identified types from rat diaphragm. Am J Physiol 1987; 253 (Cell Physiol 22): C210-C218.

13. Lowey S, Waller GS, Tyrbus KM. Skeletal muscle myosin light chains are essential for physiological speed of shortening. Nature 1993; 365: 454-456.

14. Schiaffino S, Reggiani C. Myosin isoforms in mammalian skeletal muscle. J Appl Physiol 1994; 77: 493-501.

15. Hughes SM, Cho M, Karsch-Mizrachi I, et al. Three slow myosin heavy chains sequentially expressed in developing mammalian muscle. Dev Biol 1993; 158: 183-199.

16. Schiaffino S, Ausoni S, Gorza L, Saggin L, Gundersen $\mathrm{K}$, Lomo T. Myosin heavy chain isoforms and velocity of shortening of type 2 skeletal muscle fibres. Acta Physiol Scand 1988; 134: 575-576.

17. Bottinelli R, Schiaffino S, Reggiani C. Force-velocity relation and myosin heavy chain isoform composition in skinned fibres of rat skeletal muscle. J Physiol (Lond) 1991; 437: 655-672.

18. Ennion S, Sant'Ana Pereira J, Sargeant AJ, Young A, Goldspink G. Characterization of human skeletal muscle fibres according to the myosin heavy chains they express. J Muscle Res Cell Motil 1995; 16: 35-43.

19. Smerdu V, Karsch-Mizrachi I, Campione M, Leinwand L, Schiaffino S. Type IIx myosin heavy chain transcripts are expressed in type IIb fibers of human skeletal muscle. Am J Physiol 1994; 267: C1723-1728.

20. Termin A, Staron RS, Pette D. Myosin heavy chain isoforms in histochemically defined fiber types of rat muscle. Histochemistry 1989; 92: 453-457.

21. Gorza L. Identification of a novel type 2 fiber population in mammalian skeletal muscle by combined use of 
histochemical myosin ATPase and antimyosin monoclonal antibodies. J Histochem Cytochem 1990; 38: 257-265.

22. Pette D, Staron RS. Cellular and molecular diversities of mammalian skeletal muscle fibres. Rev Physiol Biochem Pharmacol 1990; 116: 1-76.

23. Sant'Ana Pereira JAA, Moorman AFM. Do type IIb fibres of human muscle correspond to IIx/d or to IIb of rats? Proc Physiol Soc 1994; 479: 161P.

24. Schiaffino S, Gorza L, Sartore S, et al. Three myosin heavy chain isoforms in type 2 skeletal muscle fibres. J Muscle Res Cell Motil 1989; 10: 197-205.

25. Schiaffino S, Saggin L, Viel A, Ausoni S, Sartore S, Gorza L. Muscle fiber types identified by monoclonal antibodies to myosin heavy chains. In: Benzi G, Packer L, Siliprandi N, eds. Biochemical Aspects of Physical Exercise. Amsterdam, Elsevier, 1986; pp. 27-34.

26. Larsson L, Edstrom L, Lindergren B, Gorza L, Schiaffino S. Myosin heavy chain composition and enzyme-histochemical and physiological properties of a novel fasttwitch motor unit type. Am J Physiol 1991; 261 (Cell Physiol 30): C93-C101.

27. Orozco-Levi M, Gea J, Martín-Campos JM, et al. Sarcomere disruption and myosin isoform expression in the diaphragm of COPD patients. Eur Respir J 1966; 9 (Suppl. 23): 266s-267s.

28. Brozanski BS, Daood MJ, Watchko JF, LaFramboise WA, Guthrie RD. Postnatal expression of myosin isoforms in the genioglossus and diaphragm muscles. Pediatr Pulmonol 1993; 15: 212-219.

29. Watchko JF, Daood MJ, Vazquez RL, et al. Postnatal expression of myosin isoforms in an expiratory muscle, external abdominal oblique. J Appl Physiol 1992; 73: 1860-1866.

30. LaFramboise WA, Watchko JF. Brozanski BS, Daood MJ, Guthrie RD. Myosin heavy chain expression in respiratory muscles of the rat. Am J Respir Cell Mol Biol 1992; 6: 335-339.

31. Gea J, Hamid Q, Comtois N, et al. Myosin heavy chain mRNA expression in the canine diaphragm pre- and postinspiratory resistive breathing. Am J Physiol 1997; (submitted)

32. Gore MT, Young RB, Bird CR, et al. Myosin heavy chain gene expression in bovine fetuses and neonates representing genotypes with contrasting patterns of growth. Proc Soc Exp Biol Med 1995; 209: 86-91.

33. DeNardi C, Ausoni S, Moretti P, et al. Type-IIx myosin heavy chain is coded by a muscle fiber type-specific and developmentally regulated gene. J Cell Biol 1993; 123: 823-835.

34. Mahdavi V, Chambers AP, Nadal-Guinard B. Cardiac alpha- and beta-myosin heavy chain genes are organized in tandem. Proc Natl Acad Sci USA 1984; 81: 26262630.

35. Saez LJ, Gianola KM, McNally E, et al. Human cardiac myosin heavy chain genes and their linkage in the genome. Nucleic Acids Res 1987; 15: 5443-5459.

36. Weydert A, Daubas P, Lazaridis I, et al. Genes for skeletal muscle myosin heavy chains are clustered and are not located on the same mouse chromosome as a cardiac myosin heavy chain gene. Proc Natl Acad Sci USA 1985; 82: 7183-7187.

37. Leinwand LA, Fournier REK, Nadal-Guinard B, Shows TB. Multigene family for sarcomeric myosin heavy chain in mouse and human DNA: localization on a single chromosome. Science Wash DC 1983; 221: 766769 .
38. Soussi-Yanicostas N, Whalen RG, Petit C. Five myosin heavy chain genes are organized as a multigene complex in the human genome. Hum Mol Genet 1993; 2: 563-569.

39. Yoon SJ, Seiler H, Kucherlapati R, Leinwand L. Organization of the human skeletal myosin heavy chain gene cluster. Proc Natl Acad Sci USA 1992; 89: 12078 12082.

40. Dix D, Eisenberg B. In situ hybridization and immunocytochemistry in serial sections of rabbit skeletal muscle to detect myosin expression. J Histochem Cytochem 1988; 6: 1519-1526.

41. Dix D, Eisenberg BR. Spatial distribution of myosin mRNA in cardiac tissue by in situ hybridization techniques. In: Clark WA, Decker RS, Borg TK, eds. Biology of isolated adult cardiac myocites. Amsterdam, Elsevier Science, 1988; pp. 147-160.

42. Wenderoth MP, Eisenberg BR. Ultrastructural distribution of myosin heavy chain mRNA in cardiac tissue: a comparison of frozen and LR White embedment. $J$ Histochem Cytochem 1991; 39: 1025-1033.

43. Goldstein MA, Sordahl LA, Schwartz A. Ultrastructural analysis of left ventricular hypertrophy in rabbits. $J$ Mol Cell Cardiol 1974; 6: 265-273.

44. Isaacs WB, Fulton AB. Cotranslational assembly of myosin heavy chain in developing cultured skeletal muscle. Proc Natl Acad Sci USA 1987; 84: 6174-6178.

45. Eisenberg BR, Goldspink PH, Wenderoth MP. Distribution of myosin heavy chain mRNA in normal and hyperthyroid heart. J Mol Cell Cardiol 1991; 23: 287-296.

46. Wenderoth MP, Eisenberg BR. Incorporation of nascent myosin heavy chains into thick filaments of cardiac myocytes in thyroid-treated rabbits. J Cell Biol 1987; 105: 2771-2780.

47. Pattullo MC, Cotter MA, Cameron NE, Barry JA. Effects of lengthened immobilization on functional and histochemical properties of rabbit tibialis anterioris anterior muscle. Exp Physiol 1992; 77: 433-442.

48. Goldspink G, Scutt A, Martindale J, Jaenicke Th, Turay L, Gerlach GF. Stretch and force generation induce rapid hypertrophy and myosin isoform gene switching in adult skeletal muscle. Biochem Soc Trans 1991; 19: 368373.

49. Aigner S, Pette D. Fast-to-slow transition in myosin heavy chain expression of rabbit muscle fibres induced by chronic low frequency stimulation. Symp Soc Exp Biol 1992; 46: 311-317.

50. Tsika RW, Herrick RE, Baldwin KM. Interaction of compensatory hypertrophy and hindlimb suspension on myosin isoform expression. J Appl Physiol 1987; 62: 2180-2186.

51. Brownson C, Little P, Mayne C, Jarvis JC, Salmons S. Reciprocal changes in myosin isoform expression in rabbit fast skeletal muscle resulting from the application and removal of chronic electrical stimulation. Symp Soc Exp Biol 1992; 46: 301-310.

52. Leeuw T, Pette D. Co-ordinate changes in the expression of troponin subunit and myosin heavy chain isoforms during fast-to-slow transition of low-frequency-stimulated rabbit muscle. Eur J Biochem 1993; 213: 1039-1046.

53. Delp MD, Pette D. Morphological changes during fiber type transitions in low-frequency stimulated rat fasttwitch muscle. Cell Tissue Res 1994; 277: 363-371.

54. Diffee GM, Caiozzo VJ, Herrick RE, Baldwin KM. Contractile and biochemical properties of rat soleus and plantaris after hindlimb suspension. Am J Physiol 1991; 260 (Cell Physiol 29): C528-C534. 
55. Thomason DB, Herrick RE, Surdyka D, Baldwin KM. Time course of soleus muscle myosin expression during hindlimb suspension and recovery. J Appl Physiol 1987; 63: 130-137.

56. Zhou MY, Klitgaard H, Saltin B, Roy RR, Edgerton VR, Gollnick PD. Myosin heavy chain isoforms of human muscle after short-term spaceflight. J Appl Physiol 1995; 78: 1740-1744.

57. Canton F, Bigard AX, Merino D, Lienhard F, Guezennec CY. Effects of chronic low frequency stimulation on structural and metabolic properties of hindlimb suspended rat soleus muscle. Eur J Appl Physiol 1995; 70: 528-535.

58. Fauteck SP, Kandarian SC. Sensitive detection of myosin heavy chain composition in skeletal muscle under different loading conditions. Am J Physiol 1995; 268: C419-424.

59. Abernethy PJ, Jurimae J, Logan PA, Taylor AW, Thayer RE. Acute and chronic response of skeletal muscle to resistance exercise. Sports Med 1994; 17: 22-38.

60. Schiaffino S, Gorza L, Ausoni S, et al. Muscle fiber types expressing different myosin heavy chain isoforms: their functional properties and adaptive capacity. In: Pette D, ed. The Dynamic State of Muscle Fibers. Berlin, De Gruyter, 1991.

61. Pette D. Fiber transformation and fiber replacement in chronically stimulated muscle. J Heart Lung Transplant 1992; 11: S299-305.

62. Baldwin KM, Roy RR, Edgerton VR, Herrick RE. Interaction of nerve activity and skeletal muscle mechanical activity in regulating isomyosin expression. In: Benzi G, ed. Advances in Myochemistry. Proceedings of the 3rd Congress in Myochemistry. London, 1989; pp. 83-92.

63. Diffee GM, Haddad F, Herrick RE, Baldwin KM. Control of myosin heavy chain expression: interaction of hypothyroidism and hindlimb suspension. Am J Physiol 1991; 261 (Cell Physiol 30): C1099-C1106.

64. Sugiura T, Miyata H, Kawai Y, Matoba H, Murakam N. Changes in myosin heavy chain expression of overload rat skeletal muscles. Int J Biochem 1993; 25: 1609 1613.

65. Diffee GM, McCue S, LaRosa A, Herrick RE, Baldwin KM. Interaction of various mechanical activity models in regulation of myosin heavy chain isoform expression. J Appl Physiol 1993; 74: 2517-2522.

66. Fitzsimons DP, Diffee GM, Herrick RE, Baldwin KM. Effects of endurance exercise on isomyosin patterns in fast- and slow-twitch skeletal muscles. J Appl Physiol 1990; 68: 1950-1955.

67. Diffee GM, Caiozzo VJ, McCue SA, Herrick RE, Baldwin KM. Activity-induced regulation of myosin isoform distribution: comparison of two contractile activity programs. J Appl Physiol 1993; 74: 2509-2516.

68. Adams GR, Hather BM, Baldwin KM, Dudley GA. Skeletal muscle myosin heavy chain composition and resistance training. J Appl Physiol 1993; 74: 911915.

69. Coggan AR, Spina RJ, King DS, et al. Skeletal muscle adaptations to endurance training in 60 to $70 \mathrm{yr}$ old men and women. J Appl Physiol 1992; 72: 1780-1786.

70. Staron RS, Karapondo DL, Kraemer WJ, et al. Skeletal muscle adaptations during early phase of heavy-resistance training in men and women. J Appl Physiol 1994; 76: $1247-1255$.

71. Andersen JL, Klitgaard H, Saltin B. Myosin heavy chain isoforms in single fibres from $\mathrm{m}$. vastus lateralis of sprinters: influence of training. Acta Physiol Scand 1994; 151: 135-142.

72. Fitts RH, Metzger JM, Riley DA, Unsworth BR. Models of disuse: a comparison of hindlimb suspension and immobilization. J Appl Physiol 1986; 60: 1946-1953.

73. Caiozzo VJ, Baker MJ, Herrick RE, Tao M, Baldwin KM. Effect of spaceflight on skeletal muscle: mechanical properties and myosin isoform content of a slow muscle. J Appl Physiol 1994; 76: 1764-1773.

74. Buller AJ, Eccles JC, Eccles RM. Interactions between motoneurones and muscles in respect of the characteristic speeds of their responses. J Physiol (Lond) 1960; 150: 417-439.

75. Jolesz F, Sreter FA. Development, innervation, and activity pattern-induced changes in skeletal muscle. Апnи Rev Physiol 1981; 43: 531-552.

76. Pette D, Vrbova G. Neural control of phenotypic expression in mammalian muscle fibers. Muscle Nerve 1985; 8: 676-689.

77. Ausoni S, Gorza L, Schiaffino S, Gundersen K, Lomo T. Expression of myosin heavy chain isoforms in stimulated fast and slow rat muscles. J Neurosci 1990; 10: 153-160.

78. Gundersen K, Leberer T, Lomo T, Pette D, Staron RS. Fibre types, calcium-sequestering proteins and metabolic enzymes in denervated and chronically stimulated muscles of the rat. J Physiol Lond 1988; 398: 177-189.

79. Termin A, Staron RS, Pette D. Changes in myosin heavy chain isoforms during chronic low-frequency stimulation of rat fast hindlimb muscles: a single fiber study. Eur J Biochem 1989; 186: 749-754.

80. Clark B, Acker M, McCully $\mathrm{K}$, et al. In vivo $31 \mathrm{P}-\mathrm{NMR}$ spectroscopy of chronically stimulated canine skeletal muscle. Am J Physiol 1988; 254 (Cell Physiol 23): C258-C266.

81. Dewar M, Drinkwater O, Wittnick C, Chiu R. Synchronously stimulated skeletal muscle graft for myocardial repair. J Thorac Cardiovasc Surg 1985; 87: 325-331.

82. Midrio M, Danieli-Betto D, Megighian A, Velussi C, Catani C, Carraro U. Slow-to-fast transformation of denervated soleus muscle of the rat, in the presence of an antifibrillatory drug. Pflügers Arch 1992; 420: 446450.

83. Zhan WZ, Sieck GC. Adaptations of diaphragm and medial gastrocnemius muscles to inactivity. J Appl Physiol 1992; 72: 1445-1453.

84. Finol HJ, Lewis DM, Owens R. The effects of denervation on contractile properties of rat skeletal muscle. J Physiol (Lond) 1981; 319: 81-92.

85. Gauthier GF, Hobbs AW. Effects of denervation on the distribution of myosin isozymes in skeletal muscle fibers. Exp Neurol 1982; 76: 331-346.

86. Bandman E. Myosin isoenzyme transitions in muscle development, maturation, and disease. Int Rev Cytol 1985; 97: 97-131.

87. Izumo S, Nadal-Guinard B, Mahdavi V. All members of the MHC multigene family respond to thyroid hormone in a highly tissue-specific manner. Science Wash DC 1986; 231: 597-600.

88. Devor ST, White TP. Myosin heavy chain phenotype in regenerating skeletal muscle is affected by thyroid hormone. Med Sci Sports Exerc 1995; 27: 674-681.

89. Adams GR, Baldwin KM. Age dependence of myosin heavy chain transactions induced by creatinine depletion in at skeletal muscle. J Appl Physiol 1995; 78: $368-371$.

90. Sundberg CJ. Exercise and training during graded leg 
ischaemia in healthy man with special reference to effects on skeletal muscle. Acta Physiol Scand 1994; 615: 1-50.

91. Glenmark B. Skeletal muscle fiber types, physical activity in women and men: a follow-up from age 16 to 27. Acta Physiol Scand 1994; 623: 1-47.

92. Whalen RG, Sell SM, Butler-Browne GS, Schwartz K, Bouveret P, Pinset-Harstrom I. Three myosin heavy chain isozymes appear sequentially in rat muscle development. Nature (Lond) 1981; 292: 805-809.

93. Vazquez RL, Dood M, Watchko JF. Regional distribution of myosin heavy chain isoforms in rib cage muscles as a function of postnatal development. Pediatr Pulmonol 1993; 16: 289-296.

94. Larsson L, Biral D, Campione M, Schiaffino S. An agerelated type IIb to IIx myosin heavy chain switching in rat skeletal muscle. Acta Physiol Scand 1993; 147: 227-234.

95. Pette D, Dusterhoft S. Altered gene expression in fasttwitch muscle induced by chronic low-frequency stimulation. Am J Physiol 1992; 262: R333-R338.

96. Frischknecht R, Vrbova G. Adaptation of rat extensor digitorum longus to overload and increased activity. Pflügers Arch 1991; 419: 319-326.

97. Weintraub H, Davis R, Tapscott S, et al. The MyoD gene family: nodal points during specification of the muscle cell lineage. Science (Wash DC) 1991; 251: 761-766.

98. Yang S, Alnageeb M, Sympson H, Goldspink G. Clon- ing and characterisation of an IGF-1 isoform expressed in skeletal muscle. Res Cell Motility 1996; 17: 487-497.

99. Zhu E, Petrof B, Gea J, Comtois N, Grassino A. Diaphragm muscle fiber injury following inspiratory resistive breathing. Am J Respir Crit Care Med 1997; 155: 1110 1116.

100. Ianuzzo CD, Hamilton N, O'Brien PJ, Desrosiers C, Chiu R. Biochemical transformation of canine skeletal muscle for use in cardiac assist devices. J Appl Physiol 1990; 68: 1481-1485.

101. Acker M, Mannion J, Brown W, et al. Canine diaphragm muscle after $1 \mathrm{yr}$ of continuous electrical stimulation: its potential as a myocardial substitute. J Appl Physiol 1987; 62: 1264-1270.

102. Hopkins D, Manchester KL, Gregory M. Histochemical and biochemical characteristics of the transient hypertrophy of the denervated rat hemidiaphragm. Exp Neurol 1983; 81: 279-293.

103. Sugiura T, Morimoto A, Murakami N. Effects of endurance training on myosin heavy-chain isoforms and enzyme activity in the rat diaphragm. Pflügers Arch 1992; 421: 77-81.

104. Goldspink G. Mechanics and Energetics of Animal Locomotion. Chapter 3. In: Alexander RMN, Goldspink G, eds. London, Chapman and Hall, 1977.

105. Gea J, Orozco-Levi M, Aguar MC, et al. Adaptive changes concerning the type of fibres and isoforms of myosin in the external intercostal muscle of COPD patients. Eur Respir J 1996; 9: Suppl. 23, 160s. 